\title{
Post-Paris policy relevance: lessons from the IPCC SR15 process
}

\author{
Erlend A. T. Hermansen ${ }^{1}$ (D) $\cdot$ Bård Lahn $^{1} \cdot$ Göran Sundqvist $^{1,2} \cdot{\text { Eirik } \varnothing y e^{1,3}}^{1}$
}

Received: 12 January 2021 / Accepted: 26 August 2021 / Published online: 2 November 2021

(C) The Author(s) 2021

\begin{abstract}
Policy relevance is the raison d'être for the Intergovernmental Panel on Climate Change (IPCC), yet few studies have analysed what the concept entails, not least from the perspective of key target groups for the IPCC. We present a framework which enables analysis of how different actor strategies (heating up and cooling down) contribute to shape relevance-making in specific political situations when IPCC knowledge is interpreted and used. Drawing on empirical evidence from the reception and use of the Special Report on Global Warming of $1.5^{\circ} \mathrm{C}$ (SR15) across three policy making levels, the paper demonstrates different examples of creating policy relevance. First, the paper analyses the origin of SR15 and the failed attempts to formally acknowledge SR15 in the United Nations Framework Convention on Climate Change (UNFCCC) process. Second, it investigates how SR15 has been used to develop and legitimize the EU net-zero target and the European Green Deal. Third, the paper demonstrates how SR15 has been used both for legitimizing and challenging climate policy at the national level, using the example of Norway. In sum, the reception of SR15 demonstrates that while IPCC outputs have resulted in controversy at the international level, they have been highly relevant at regional and national levels. The analysis shows that policy relevance is contextdependent and indirect — created through processes involving many actors, institutions, and types of knowledge. Situating these findings within the larger shift in the international climate regime implied by the Paris Agreement, the paper concludes with a set of empirically grounded recommendations for how the IPCC may approach the goal of policy relevance post-Paris.
\end{abstract}

This article is part of the topical collection "Climate Change Communication and the IPCC", edited by Saffron O’Neill and Roz Pidcock.

Erlend A. T. Hermansen

erlend.hermansen@ cicero.oslo.no

1 CICERO Center for International Climate Research, Oslo, Norway

2 Department of Sociology and Work Science, University of Gothenburg, Gothenburg, Sweden

3 TIK Centre for Technology, Innovation and Culture, University of Oslo, Postbox 1108 Blindern, 0317 Oslo, Norway 
Keywords IPCC $\cdot$ Policy relevance $\cdot$ Political situations $\cdot$ Heating up $\cdot$ Cooling down $\cdot$ Climate policy

\section{What is policy relevance, and how is it made?}

Since its inception in the 1980s, global climate policy has been dominated by ideals of a strong link between scientific expertise and political decision-making (Agrawala 1998a; Miller 2004). The idea of a scientifically driven response to climate change is easily discernible in the close relationship between the scientific assessment work of the Intergovernmental Panel on Climate Change (IPCC) and the policy processes taking place under the auspices of the United Nations Framework Convention on Climate Change (UNFCCC) (Agrawala 1998a, 1998b). Today, parties in the Paris Agreement recognize "the need for an effective and progressive response to the urgent threat of climate change on the basis of the best available scientific knowledge" (UNFCCC 2015 p. 21, emphasis added). Correspondingly, "the objective of the IPCC is to provide governments at all levels with scientific information that they can use to develop climate policies" (IPCC 2021a, emphasis added). That said, the official IPCC self-image is that the work of the organization is "policy-relevant and yet policy-neutral, never policy-prescriptive" (IPCC 2021b), which means that a clear boundary is set up between science and policy. Science should inform policy but not intervene in, nor be influenced by political decisionmaking.

The IPCC has maintained an important role in establishing "dangerous climate change" as a concern that needs to be mitigated at the global level (Edwards 2010), and particularly in defining what "dangerous climate change" might mean, for example in terms of temperature limits or tolerable levels of risk (Mahony 2015; Randalls 2010). This role has implied a direct relationship to policymaking at the international level (Miller 2004), on the assumption that the primary audience of the IPCC's reports is to be found among UNFCCC negotiators developing common rules and targets in a "top-down", monocentric multilateral policy regime.

With the adoption of the Paris Agreement in 2015, however, a move away from the previous top-down model of the Kyoto Protocol and towards a more decentralized policy regime has taken place (Jordan et al. 2018; Guillemot 2017). This change in the structure of the climate policy regime places new requirements on the IPCC to provide information that is more specifically oriented towards geographically diverse contexts (Livingston et al. 2018). This new phase in the relationship between the IPCC and the UNFCCC has been referred to as a "solution-oriented" mode (Jabbour and Flachsland 2017), which according to some commentators is changing "the very meaning of policy-relevant science" (Livingston et al. $2018 \mathrm{p}$. 89). Also, the chair of the IPCC has indicated that a focus on solutions will be important part of his tenure, and that the IPCC can "better serve global policy-makers by providing a more indepth, and clear, understanding of the solutions" (Lee 2015 p. 1007).

An important reason for this sharper focus on solutions is the "bottom-up" structure of the Paris Agreement, in which targets and policies primarily are developed and adopted nationally, but assessed globally. The Paris Agreement institutionalizes a set of global goals to which national policies should contribute: to keep global temperature rise to "well below $2{ }^{\circ} \mathrm{C}$ " compared to pre-industrial levels, to "pursue efforts" to limit warming to $1.5^{\circ} \mathrm{C}$, and to achieve a global "balance" between sources and sinks of greenhouse gases (GHGs) by the end of this century (the "net-zero" goal). This shifts attention from diagnosing the problem and establishing goals (in terms of a definition of "dangerous climate change") towards defining potential 
pathways for how specific goals could be reached (Beck and Mahony 2018). This implies a fundamental restructuring of the international climate regime, with important implications for the role of scientific advice in the policy process. The IPCC is now in a position where national-level policy processes will be decisive, while the international level will continue to play a role in assessing, coordinating and increasing the ambition of national efforts. How the IPCC can fulfil its mandate and be policy relevant in this more complex, polycentric, and nationally oriented policy terrain post-Paris, where impacts of and responses to climate change become more diverse, is a question of great importance.

When the world's governments hammered out the agreement in Paris, the UNFCCC also directly requested the IPCC "to provide a special report in 2018 on the impacts of global warming of $1.5^{\circ} \mathrm{C}$ above pre-industrial levels and related global greenhouse gas emission pathways" (SR15) (UNFCCC 2015 p. 4). This is the first time the UNFCCC formally invites the IPCC to produce a (specific) report in response to a clearly specified question. In this report the IPCC presents possible pathways to limit global warming to $1.5^{\circ} \mathrm{C}$ showing that the ambitious goal is possible to reach, and by what potential means. By accepting the invitation and producing a report presenting potential solutions to specified (however ambiguous) political ambitions make SR15 a clear example of the IPCC in a more solution-oriented mode, and thus a prominent case through which to investigate the IPCC's policy relevance post-Paris. The aim of this paper is to investigate the new development in the IPCC-UNFCCC trajectory after 2015 by studying policy relevance in relation to this specific IPCC report.

Previous empirical analyses of the policy relevance of the IPCC have suggested that the IPCC seems to presume that policy relevance is made through the very processes of producing the reports, for instance the scoping process, multiple rounds of review (both experts and governments), and the approval process of the most prominent document in terms of policy relevance, the Summary for Policy Makers (SPM) (Sundqvist et al. 2015; Hermansen et al. 2018). More recent studies conducted post-Paris have engaged with the notion of policy relevance from the perspective of the IPCC and its contributing scientists (Livingston et al. 2018; Lahn 2020) or discussed how policy relevance can be interpreted or achieved (see, e.g., Riousset et al. 2017). While these perspectives have made important contributions to understand policy relevance, they have largely neglected the specific situations in which policy relevance is made, and the significance of actors other than the IPCC for making policy relevance. In line with the bottom-up structure in the Paris Agreement, such situations of relevance-making will take place at the regional and national levels (and beyond), just as much as at the global level, and involve numerous actors and strategies within and across levels. This implies to focus more on outcome compared to process when discussing and judging the policy influence of the IPCC (Agrawala 1998b). "Outcome" has so far not been a prioritized focus for the IPCC's self-understanding of being "policy-relevant and yet policy-neutral, never policy-prescriptive" (IPCC 2021b). Nor has it been an important topic for social science research. In addition, the focus on "process" has mostly been limited to the global level (Hermansen et al. 2018). We argue that to grasp what policy relevance means post-Paris we must study in empirical detail how IPCC knowledge is made relevant for policy — and for climate action more broadly — across levels and contexts. This means studying the situations in which policy relevance is produced, including the actors involved and the strategies they employ in these situations

The main objective of this paper is to analyse policy relevance of the IPCC post-Paris, focusing on different impacts of SR15. The topic is analysed through examples across three governance levels (global-UNFCCC, regional-EU, national-Norway), which are then discussed within the larger context of climate governance post-Paris. Methodologically, we 
take an interpretive qualitative approach, grounded in a close reading of key policy documents. For the regional and national examples, submitted Nationally Determined Contributions (NDCs) and the policy documents on which they build were analysed to identify instances in which the IPCC and SR15 were invoked, and how. For the global-level example, a similar reading of UNFCCC decisions relating to SR15 was combined with insights from participant observation at COP 21 (Paris, 2015), SBSTA 48 (Bonn, 2018) and COP 24 (Katowice, 2018). For all three examples, the original material was combined with extant literature and media reports in order to reconstruct the political situation in which the policy documents were developed and to identify actor strategies as further defined below.

In the next section, we review the most relevant literature and lay out a conceptual framework for analysing policy relevance in political situations by focusing on actor strategies. Next follows the three empirical examples, which are analysed in the final section. We conclude that the IPCC should take a broader perspective on policy relevance, as something that is not only achieved through scientific consensus and formal policy processes, but also through feedback cycles between science and policy, and not least outside policy processes, through contestation and actions by a multitude of actors.

\section{Conceptualizing IPCC policy relevance post-Paris}

Due to the important role ascribed to climate science in the development of international climate policy, and the institutionalized role of the IPCC as the primary provider of scientific knowledge in the policy process, the IPCC's policy relevance and impact on policy development has often been understood in accordance with a linear model of expertise (Beck 2011). IPCC as the "producer" or "sender" of scientific information is positioned in relative isolation from the "consuming" or "receiving" policymakers. From this perspective policy relevance means communicative effectiveness, analysed for example through the framing of reports (O’Neill et al. 2015). Knowledge production is seen as prior to and distinct from policymaking, and the challenge thus is to overcome communicative or other barriers that may otherwise prevent "turning science into policy" (Watson 2005; cf. Edenhofer and Minx 2014). This view is an important component in the dominant IPCC self-image of being "policy-relevant and yet policy-neutral".

However, the assumption of a linear transmission from a scientific "sender" to "receiving" policymakers has been questioned as being a too simplified or even false description of science-policy interactions, and for not serving the climate issue well (see, e.g., Beck 2011). An alternative understanding has been proposed, focusing on how scientific and political processes interact to establish climate change as both knowable and governable, i.e., a coproduction of science and social order (Jasanoff 2004). The co-productionist perspective has primarily been developed within the interdisciplinary field of Science and Technology Studies (STS), where the mutual interaction between the IPCC and the UNFCCC is seen as a paradigmatic case of co-production (Mahony and Hulme 2018).

In a co-productionist account, policy relevance becomes a relational achievement that emerges in the interaction between scientific knowledge and situations of policymaking. Such interactions should not be studied as something static, but rather as evolving through trajectories (Sundqvist et al. 2015). The adoption of the Paris Agreement, which has been described as "a fundamental re-alignment of the relationship between international climate science and policy" (Beck and Mahony 2018 p. 1), can be seen as a new development in the trajectory of 
the IPCC-UNFCCC relationship, which merits a renewed discussion about what policy relevance means and how it is achieved.

In this paper, when analysing the policy relevance of SR15, we want to elaborate on ways to understand relevance from a co-productionist approach by focusing on the concept of political situations as "a way of understanding the role of the production of knowledge in the practice of politics" (Barry 2012 p. 330). Controversies over the application of scientific knowledge are then situated in a larger context marked by a high degree of indeterminacy. Such controversies should not be understood in isolation, but must "be conceived in terms of its relations to a moving field of other controversies, conflicts and events" which "have occurred elsewhere and at other times" (Barry 2012 pp. 330-324) - while avoiding the "mistake to assume that specific knowledge controversies are simply the manifestation or expression of larger scale forces" (Barry 2012 p. 333). The challenge, in other words, is to take seriously the details of how some knowledge comes to matter and some does not, while at the same time situating these controversies in the field of diverse political disagreements in which they play out.

Applying this approach to the study of policy relevance, we see relevance as something that is achieved in specific conjunctures of policy processes. Relevance-making thus requires an active effort, not just by the scientific "sender" of information, but just as much by actors traditionally seen as more passive "users" or "recipients", as part of these actors' work to "establish connections between distinct disputes, building up a sense of a temporally and spatially extended political situation" (Barry 2012 p. 330). The political situation helps determine which knowledge is relevant, while at the same time being co-constituted by the same knowledge. To comprehend policy relevance, therefore, we propose to study relevancemaking in the political situations in which it occurs.

The focus of this paper is therefore placed on actor strategies that render IPCC knowledge more or less useful in political situations outside the IPCC process. To better grasp these strategies, we distinguish between attempts of "heating up" and "cooling down" (Sundqvist 2014). The first strategy, cooling down, seeks to establish a clear separation between the scientific and the political. Science is made relevant as a resource for stabilizing political situations, by appealing to scientific authority in order to overcome disagreement or "anchor" specific policy ambitions (van der Sluijs et al. 1998). By contrast, the strategy of heating up employs scientific knowledge explicitly to strengthen a specific position in a political controversy. Implicit in this latter strategy is a recognition that in a political situation about a sciencerelated issue, such as climate change, a clear separation between science and policy-as assumed in the linear model - is questioned. A heating-up strategy seeks to create relevance for science by connecting more closely with other relevant and central actors, often by simultaneously broadening the frame of the issue (Marres 2007). In short, the heating-up strategy means to include more actors and more issues. The two strategies display different ways to manage science-policy interactions, and in political situations of conflict, uncertainties and tensions, the strategies become more visible.

The SR15 report stands out as a particularly relevant case for analysing these dynamics. The report was requested specifically by the UNFCCC as part of the decision that adopted the Paris Agreement, and in direct response to the Agreement's new goal of pursuing efforts to limit warming to $1.5^{\circ} \mathrm{C}$. It has been argued that this request is representative of a new situation in which the IPCC is expected to "more directly service the needs of governments", and that it therefore "refocuses attention on the function and status of the IPCC as an institution that mediates between climate science, governance and policy" (Hulme 2016 pp. 222-223). 
Taken together, the concept of political situations and the strategies of "heating up" and "cooling down" will inform our analysis of how relevance-making occurs. The framework equips us with conceptual optics to study the suggested shift in the IPCC's position between science and policy by focusing on SR15 in three different contexts, or political situations. In the following, we use the report to investigate what policy relevance is and how it is created in connection to the IPCC and climate action.

\section{Political situations of relevance-making: three examples}

In this section, we present empirical examples of relevance-making in political situations across three governance levels - the global (UNFCCC), the regional (the EU), and the national (Norway) - and discuss actors' strategic use of SR15 in light of the notions of "cooling down" and "heating up". The examples represent different spaces within the varied "epistemic geographies of climate change" (Mahony and Hulme 2018) that may be used to highlight differences in how policy relevance plays out and the strategies actors make use of. They can be said to represent a "mostlikely" case selection (George and Bennett 2005 pp. 121-122) for the investigation of IPCC relevance, in that all three governance levels have historically had strong links with the IPCC and emphasized the value of IPCC knowledge (Eckersley 2016; Lövbrand 2011; Miller 2004). As such, they are not meant to provide a comprehensive picture of how IPCC reports are used always and everywhere. Rather, they illustrate differences which point to the need for discussions about policy relevance to take into account the specificities of political situations in which relevance is at stake and IPCC knowledge is put to use.

\subsection{The UNFCCC: requesting an unwelcome report}

Our first example of a political situation in which the relevance of SR15 was at stake is the UNFCCC negotiations following the adoption of the Paris Agreement. Although not explicit in the Paris Agreement, an important reason why the UNFCCC invited the IPCC to provide SR15 in the first place was to arrange for the report to feed into a so-called "facilitative dialogue" at COP 24 , with the aim "to take stock of the collective efforts of Parties in relation to progress towards the longterm goal" of the Agreement (UNFCCC 2015 p. 4). In other words, parties to the UNFCCC had direct expectations to the IPCC in terms of policy relevance post-Paris.

The "facilitative dialogue" (later dubbed the "Talanoa dialogue") was agreed as part of the adoption of the Paris Agreement and was regarded by many as a "dress rehearsal" for the so-called Global Stocktake (hereafter GST). The GST is at the heart of the Paris Agreement, as it is the main mechanism through which parties will collectively assess the adequacy of national mitigation efforts in relation to the global goal of the agreement (Rajamani 2016). The process will take place every five years (starting in 2023) and form the basis for subsequent adjustments (and strengthening) of parties' NDCs. According to the Paris Agreement, the GST will be undertaken in the light of "the best available science", of which the IPCC's reports are assumed to be central (Lahn 2018). It was expected that SR15 would play a similar role as a key input to the Talanoa dialogue. This is evident in the foreword to the report, which states that the IPCC worked in "record time" to present the report in time for COP 24 (IPCC 2018 p. vi).

Against this background, it may seem surprising that when SR15 was formally presented to the UNFCCC at COP 24 in Katowice, Poland, December 2018, it was not universally praised as important input to the Talanoa dialogue. On the contrary, the report became a contentious 
topic in itself, as the COP could not reach a decision about how the report was to be received. In short, a handful of major fossil fuel producing countries (including the USA, Russia, Kuwait, and, perhaps most visibly, Saudi Arabia) refused to accept a text in which the COP "welcomed" the report, insisting instead on a less welcoming decision that would "take note" of it. The reasons they gave was that the report highlighted significant knowledge gaps about the 1.5 target and did therefore not represent a full scientific basis in the same way as "regular" IPCC assessment report would (Hickman 2018).

After a series of failed attempts at reaching agreement on the issue in Katowice, it was postponed to a lower-level meeting in Bonn, June 2019. Also at this meeting, disagreement about the report resulted in a high level of conflict. Eventually, the COP ended up thanking the IPCC for responding to the invitation made in Paris and acknowledging that the report reflects "the best available science", however without adopting any decision regarding how to act on the knowledge. This led influential commentators to conclude that "climate science was buried at a meeting in Bonn" (Farand 2019).

How can we understand the reluctance at COP 24 to welcome a report that the UNFCCC explicitly had invited the IPCC to produce as input to the meeting, and which the same governments had approved in an IPCC plenary just a few weeks back? Does the disagreement about the report mean that SR15 failed to gain relevance at the level of the UNFCCC and the Talanoa dialogue it was expected to inform? We propose a different answer, namely that the heated controversy over the report itself is suggestive of a particular way in which the report was made relevant. In order to understand this, we need to analyse the disagreement in Katowice not as an isolated controversy but as part of a political situation with ties back to the negotiation of the Paris Agreement itself, and even further back in the history of the UNFCCC.

The decision by COP 21 to invite the IPCC to provide a special report on $1.5^{\circ} \mathrm{C}$ must be seen together with the Paris Agreement's ambition to "pursue efforts to limit the temperature increase to $1.5^{\circ} \mathrm{C}$ above pre-industrial levels" (UNFCCC 2015 p. 22). The inclusion of the $1.5^{\circ} \mathrm{C}$ ambition in the Paris Agreement was in turn the culmination of many years of disagreement over how to interpret the objective of the UNFCCC to "prevent dangerous anthropogenic interference with the climate system", going all the way back to the establishment of the UNFCCC in 1992 (Oppenheimer and Petsonk 2005).

In the Copenhagen Accord from COP 15 in 2009, the objective of the UNFCCC was operationalized into the $2^{\circ} \mathrm{C}$ target, which had been promoted as a limit for "dangerous climate change" by the EU in particular (Randalls 2010). Several developing countries had however been pushing for a stricter definition of dangerous climate change, most notably the Alliance of Small Island States (AOSIS) who had been promoting a $1.5^{\circ} \mathrm{C}$ target, and the Africa Group who argued for a $1{ }^{\circ} \mathrm{C}$ limit. As a concession to these groups, the Accord also contained a provision that the implementation of the Copenhagen Accord would be assessed by 2015, including "in relation to temperature rises of 1.5 degrees Celsius" (UNFCCC 2009 p. 7). This was later followed up through the "Structured Expert Dialogue" between IPCC scientists and UNFCCC policy makers in the period 2013-2015 (Tschakert 2015; Guillemot 2017; Livingston and Rummukainen 2020).

The final references to the $1.5^{\circ} \mathrm{C}$ ambition in the Paris Agreement and the corresponding invitation for the IPCC to produce SR15 is a political compromise that "pleased nearly everyone" (Guillemot 2017 p. 5). Put bluntly, the most vulnerable countries won a concession through the explicit mentioning of $1.5^{\circ} \mathrm{C}$ ambition and the corresponding IPCC report, while developed countries avoided explicit commitments to financial compensations, and countries reluctant to strong global targets were satisfied that the $1.5^{\circ} \mathrm{C}$ ambition was sufficiently non- 
binding. In other words, the invitation to the IPCC to produce SR15 was an integral part of an attempt to "cool down" a political situation at the heart of the UNFCCC negotiations, by delegating a detailed consideration of the more radical target to the scientific authority of the IPCC. It was part of a compromise in which some parties - the island states and several other developing countries - were clearly more attached to the $1.5^{\circ} \mathrm{C}$ target, whereas some larger countries and fossil-fuel producers were highly sceptical, and yet others were in a more neutral position.

Consequently, the production, reception, and use of SR15 in itself must be understood as part of making the $1.5^{\circ} \mathrm{C}$ target more or less relevant in relation to the overall global goal of the Paris Agreement. Examples to confirm this understanding can be found throughout the IPCC's process of producing the report. When the IPCC accepted the invitation to produce SR15 at its first plenary session after COP 21 in Paris, Saudi Arabia had strong opinions about the title of the report, seeking to balance the reference to $1.5^{\circ} \mathrm{C}$ with reference to other principles and objectives such as sustainable development and poverty eradication (ENB 2016 p. 10). At the following IPCC meeting, which was set to agree on the outline of the report, parts of the text that would ensure that the report considered "strengthened response options" was removed along with other elements, following lengthy negotiations.

Finally, in the report's approval meeting the report faced an "unusually difficult review" in which "much of the underlying tension was fed by spillover from unresolved issues in the UNFCCC process" (ENB 2018 p. 20). Saudi Arabia strongly opposed direct reference to NDCs and the Paris Agreement, and the USA "underscored that the Panel's acceptance of the SR15 does not imply its endorsement of the report's findings" (ENB 2018 p. 19).

Again, we see that disagreements about the status of the report are not isolated controversies over knowledge relevant to climate policymaking. Rather, they are enmeshed in a wider political situation and a longer historical trajectory. Within the UNFCCC, SR15 was always directly related to disagreements about the global temperature target, and more precisely about the status of the $1.5^{\circ} \mathrm{C}$ ambition in relation to the $2^{\circ} \mathrm{C}$ limit. Linking the report to the Paris Agreement (in the IPCC process) and linking the UNFCCC negotiations to the report (by "welcoming" it or using it in the Talanoa Dialogue in Katowice) were both acts of "relevancemaking" because they made the high-level message of $1.5^{\circ} \mathrm{C}$ as a necessary and achievable target more relevant, and thus strengthened the status of $1.5^{\circ} \mathrm{C}$ within the Paris Agreement. In order to appreciate them as acts of relevance-making, however, they must be understood in relation to a political situation in which the delicate compromise of Paris is constantly being challenged and renegotiated. In this context, the relevance lies not so much in the specific findings of SR15, but in the report itself and how it is being invoked within the UNFCCC negotiations.

\subsection{The EU: developing its pathway to net-zero in $\mathbf{2 0 5 0}$}

The EU has for many years been seen as a leader in UNFCCC processes and set ambitious climate targets for the union closely aligned with key IPCC findings and processes (Randalls 2010; Lövbrand 2011). In the Paris Agreement negotiations, the EU was among the actors who pushed for inviting the IPCC to produce SR15. Just a few days prior to the IPCC approval of SR15 in October 2018 a spokesperson for the European Commission (hereafter EC) said in an interview: "The IPCC special report, once adopted, will present crucial scientific input for our long term strategy" (emphasis added) (Mathiesen and Sauer 
2018). About a year later, the EC presented its proposal for a European Green Deal (hereafter EUGD), aiming for the EU to achieve net-zero emissions by 2050.

A typical situation in which the IPCC may be expected to become relevant post-Paris is in the process of preparing and developing NDCs and underlying policy documents. Comparing NDCs that were submitted in 2015 (before the Paris Agreement) and the updated version submitted in 2020 (after the publication of SR15) can therefore shed light on how SR15 figures in the formulation of overarching climate policy targets. The EU submitted its enhanced NDC in December 2020. The main substantial difference from the 2015 to the 2020 NDC is that the mitigation target is raised from 40 to $55 \%$ net domestic reduction of GHG emissions by 2030 compared to 1990 -levels, and that the EU's objective of becoming climate neutral by 2050 is stated.

Notably, there is also a change in how the EU argues for the fairness of its contribution. In the 2020 NDC, under the subheading "Fairness considerations, including reflecting on equity", there is explicit reference to SR15: "The IPCC Special Report on global warming of $1.5^{\circ} \mathrm{C}$ shows that pathways limiting warming to $1.5^{\circ} \mathrm{C}$ typically achieve net zero greenhouse gas emissions at global level in the second half of this century. This enhanced NDC is in line with the EU's agreed objective of achieving a climate-neutral EU by 2050 . The EU therefore considers the enhanced NDC to be a fair contribution towards the global temperature goal of the Paris Agreement" (EU 2020 p. 18). In other words, the EU uses SR15 and its global pathways as a metric for legitimizing that the new long-term goal of the EU is a fair contribution to the global effort - a powerful example that pathways from the IPCC are used as an anchoring device (van der Sluijs et al. 1998) for justifying climate targets.

Also, in the 2015 NDC the EU uses the IPCC to legitimize the fairness of its NDC, but in a different manner, namely "in the context of necessary reductions according to the IPCC by developed countries as a group, to reduce its emissions by $80-95 \%$ by 2050 compared to 1990 " (EU 2015 p. 3), and "consistent with the need for at least halving global emissions by 2050 compared to 1990" (ibid.). This comparison of the EUs 2015 and 2020 NDC demonstrates a transition from a $2^{\circ} \mathrm{C}$ target to $1.5^{\circ} \mathrm{C}$. In this manner the EU contributes to establish the $1.5^{\circ} \mathrm{C}$ aspirational target as the most prominent of the two temperature goals in the Paris Agreement. This shift is framed as a response to SR15, confirming the observation above that SR15 is made relevant partly to increase the relevance of the $1.5^{\circ} \mathrm{C}$ target relative to the $2^{\circ} \mathrm{C}$ target of the Paris Agreement.

The targets of the 2020 EU NDC rests on a large body of underlying policy documents and processes. In the EC's proposal to put the net-zero target of the NDC into law, the target is argued to be "in line with scientific findings reported by the IPCC" (EC 2020 p. 2), and SR15 is described as providing a "strong scientific basis for tackling climate change" (EC 2020 p. 9). The EU's overarching climate policy framework thus establishes a strong link to the IPCC and SR15 findings, however without being specific regarding which parts of SR15 it refers to. This indicates a rather generic form of policy relevance, using SR15 primarily as an anchoring device for a specific target.

The specific uses of SR15 become clearer as we follow traces of SR15 in other policy documents underlying the EU's targets. The EUGD Communication, for example, presents the climate challenge as "urgent" (EC 2019 p. 2) and "this generation's defining task" (EC 2019 p. 2), referring to SR15 when summarizing the consequences and challenges of climate change. In the communication "A Clean Planet for All", SR15 is referred as what "confirms" (EC 2018 a p. 5) the need to limit climate change to $1.5^{\circ} \mathrm{C}$. In the Communication it is stated that SR15 "has been duly taken into account" (EC 2018a p. 5) when the EC was "preparing this EU strategy" (EC 2018a p. 5). An accompanying in-depth document refers to SR15 as "new 
scientific evidence" (EC 2018b p. 17) which makes this the "time to update the evaluation of the EU's possible contribution to global action" (EC 2018b p. 17), i.e., the Paris Agreement.

The in-depth document consistently focuses on mitigation pathways; about half of the almost 400 pages is devoted to pathways. However, the in-depth document does not directly use pathways from SR15 but presents and discusses self-commissioned pathways in a separate chapter (EC 2018b pp. 53-230). SR15 is referred to and compared against in general terms on several occasions together with other knowledge sources, such as the International Energy Agency (IEA) (see, e.g., EC 2018b, p. 273 and p. 355).

The policy documents refer to SR15 mostly as a way of giving an overview of the challenges, urgency and scale of climate change, repeatedly referring to the IPCC as a provider of the "best available scientific evidence". Key messages from SR15 are transformed into implicit imperatives in the policy documents, by employing verbs such as "confirming" and "emphasizing" the need for a strengthened response. However, the documents do not specify concrete policies or response measures with reference to SR15; that seems to be commissioned and crafted in-house. In all, our analysis of the policy documents points to a specific way in which SR15 is invoked and made relevant: as a way of stabilizing or "anchoring" the EU's climate policy ambition. The most prominent actor in this instance, the EC, can thus be said to employ a "cooling down" strategy, based on a linear view of science-policy interactions in which authoritative science is used to justify its overall targets.

Why would the EU craft such a comprehensive policy response, besides the Paris Agreement obligation to submit an enhanced NDC? Clearly, the EC is not the only actor to react to SR15. The report and its key messages have also been used by nonstate actors to "heat up" the political situation, by demanding a comprehensive policy response to steadily growing GHG emissions globally. The most prominent example of this is probably the Fridays for Future movement. In August 2018, a couple of months before SR15 was released, Greta Thunberg performed the first school strike in front of the Swedish Parliament, alone. School strikes became a world-wide phenomenon in a short period of time. In September 2019, about two months after Ursula von der Leyen was elected President of the European Commission, Angela Merkel in Germany responded to public protests by launching a $€ 54$ billion climate mitigation package. According to Deutsche Welle, "Merkel highlighted Greta Thunberg's plea to "unite behind the science"" (Niranjan 2019). Fridays for Future Germany on their side "criticized the climate package as insufficient" (ibid.). About two months later, van der Leyen presented the first draft of the EUGD, in what she referred to as "Europe's man on the moon moment" (Ekblom and Baczynska 2019). The Fridays for Future engagement can be seen as a heating up strategy: public engagement for dealing with a controversial situation, that is, record high GHG emissions completely at odds with the obligations in the Paris Agreement, while von der Leyen's response can be seen as a cooling down strategy.

The analysis of the EUGD policy documents alone may leave the impression of routine policymaking. However, the process of developing the EUGD has clearly taken place in a wider political situation. It was expected that some EU countries would be reluctant to take on more ambitious climate obligations. Consequently, the documents have been on several public hearings and consultations among member states and other interested parties, which is a process of heating up. These broad hearings have generated changes to the initial Green Deal proposal from the EC. For instance, several member states, and most notably Poland, have protested against the net-zero 2050 target (Rankin 2019). Consequently, the final Green Deal 
documents specify that not necessarily all EU countries will reach net-zero simultaneously. Also issues such as "just transition" have become central parts of the EU Green Deal because of processes of heating up by member states. For instance, just transition was made a significant topic by the Polish presidency at COP 24 in Katowice, the coal heart of Europe.

Overall, the impact of SR15 on EUGD and its thorough knowledge base can be seen as an attempt at cooling down a long-lasting hot political situation: soaring global GHG emissions and lack of action. The EUGD was made possible through several heating up processes (more actors and issues were dealt with) - and is highly likely to cause more heat in the future.

\subsection{Norway: stabilizing national policy ambition}

Like the EU, Norway has historically followed the ideal of a scientifically driven climate policy - emphasizing international commitments and the scientific authority of the IPCC (Eckersley 2016). At the same time, the country has struggled to contain its domestic greenhouse gas emissions due to a large oil and gas sector with soaring GHG emissions. This has resulted in a strong emphasis on a globally cost-efficient approach to climate policy, based on flexible commitments and various forms of carbon trading, as well as heated political controversy over the level of domestic emission reductions (Boasson and Lahn 2017).

When Norway submitted an updated NDC in 2020, it was among the very first countries to officially raise the ambition of its targets following the adoption of the Paris Agreement. In its NDC prior to Paris (Government of Norway 2015), Norway had pledged a $40 \%$ emission reduction from 1990 levels by 2030. In the updated NDC (Government of Norway 2020), this target was strengthened to a 50-55\% emission reduction.

Both the first and second version of Norway's NDC refers explicitly to the IPCC and its latest reports. The first version states that the "scientific basis" for assessing the fairness and ambition of an NDC "is the most recent assessment report by the IPCC" (Government of Norway 2015 p. 5) - which at the time was the AR5 report. The second version of the NDC is even more explicit, stating that "Norway's climate targets and polices are developed in the context of best available science and hence the IPCC Special Report on 1,5 degrees, has been central to the assessment of the nationally determined contribution" (Government of Norway 2020 p. 10, emphasis added).

At the same time, the NDCs also reveal a specific pattern when it comes to which elements of the IPCC reports they relate to. In both cases, the NDCs refer directly to global emission pathways laid out in the respective IPCC reports. In the first version, this includes only pathways for keeping warming below $2^{\circ} \mathrm{C}$, which was Norway's preferred global goal at that time of writing as well as the main focus of AR5. The NDC states that Norway's - $40 \%$ target is "well in line with" the AR5 pathways for $2^{\circ} \mathrm{C}$, and that therefore "Norway is doing its fair share for the global goal of keeping global warming below $2{ }^{\circ} \mathrm{C}$ " (Government of Norway 2015 pp. 5-6). In the second version, the NDC refers to SR15 pathways for both $2^{\circ} \mathrm{C}$ and $1.5^{\circ} \mathrm{C}$. The NDC then states that "Norway's nationally determined contribution is in line with the emissions pathways towards 2050 and onwards that correspond to keeping global warming in line with the global long-term goal of the Paris Agreement"-without specifying whether this refers to the $2^{\circ} \mathrm{C}$ or $1.5^{\circ} \mathrm{C}$ goal (Government of Norway 2020 p. 15).

Comparing the two versions of Norway's NDC, in other words, provides two insights of particular interest. On the one hand, the updated NDC does rely on SR15 to justify Norway's ambition level. It is invoked in the context of increasing Norway's ambition, which can be said 
to be in line with the adoption of the $1.5^{\circ} \mathrm{C}$ target and the findings of SR 15 since its first NDC was submitted. On the other hand, because of increased ambiguity in terms of how the longterm global goal of the Paris Agreement should be interpreted (whether it is $1.5^{\circ} \mathrm{C}$ or $2^{\circ} \mathrm{C}$, what kinds of pathways - overshoot or not, etc.) the specific target of the NDC is less directly connected to the quantified ranges provided by SR15 than it was connected to the AR5 ranges in the first NDC.

In other words, SR15 became relevant in the process of updating Norway's NDC specifically through its quantified emission pathways. The report helped justify an increase in Norway's climate policy ambition, although it also led to increased ambiguity regarding exactly how Norway's NDC relates to global temperature targets. What, then, was the specific situation in which SR15 came to be relevant in this particular way?

As mentioned above, the question of national reduction targets for greenhouse gas emission has a long and contentious history in Norwegian politics. While there has been broad political agreement that Norway should pursue an international role as a climate policy "front-runner", the country has seen intense political conflict over how this role should be pursued. The larger political parties (Labour and Conservative) have generally guaranteed a policy of modestly ambitious targets achieved through various forms of carbon trading. They have however been constantly criticized by several smaller left and centre parties, as well as by the environmental movement, for not making more ambitious cuts in domestic emissions (Boasson and Lahn 2017).

Following the publication of SR15 in late 2018, the climate issue took on increasing importance in Norwegian politics. The report received wide media coverage and was also frequently invoked by a growing youth movement associated with the "Fridays for Future" school strikes. In early 2019, tens of thousands of children and youth skipped school and marched in Norwegian cities. The main demands they presented to the Minister of Climate and Environment was for Norway to increase its 2030 emission reduction target from the existing 40 to $60 \%$, and to cease further oil exploration (Bøyum et al. 2019; Holmes 2019). The demands were taken up by opposition parties in Parliament, who demanded that the government increase Norway's 2030 ambitions in light of the Paris Agreement and SR15 (Holmes 2019).

Around the same time, the coalition government led by the Conservative party was expanded to include two of the smaller parties traditionally in favour of more ambitious domestic emission reduction targets. The political negotiations about forming an expanded government coalition led to a declaration, adopted in January 2019, which concluded that the government should "submit a strengthened climate target to the UN in 2020". The declaration directly referenced the recent publication of SR15, which "shows that climate change will be dramatic" and that "the world needs a quicker and more wide-reaching transition than previously assumed" (Government of Norway 2019 pp. 83-84, our translation).

Norway's updated NDC, in other words, was shaped in a political situation at the confluence of several important factors: a historical trajectory of recurring political conflict regarding the level of emission reductions and what this would mean for the future of Norwegian oil production; a new mass mobilization among youth using SR15 to demand bolder climate action; and a change in government by which two of the "greener" parties in Norwegian politics became involved in negotiating a new government platform. In this situation, SR15 was made relevant by several actors seeking to "heat up" the discussion about Norway's climate policy. The greener political parties used the report's findings about the difference between $1.5^{\circ} \mathrm{C}$ and $2^{\circ} \mathrm{C}$ to underpin a sense of urgency and need for change in 
governmental negotiations. The school strikers invoked the report's carbon budgets to argue for a halt to oil exploration and a strengthened emission reduction target. Based on the report's emission pathways, as well as principles of justice discussed in the report and elsewhere, they further demanded a Norwegian emission reduction target well above what would be required globally. Thus, in these processes of "heating up", a wide array of the report's findings was made relevant and connected to other knowledge claims and principles.

As soon as government negotiations had concluded and a new target of 50-55\% emission reductions had been agreed, we see a different form of relevance-making. As shown above, the updated NDC submitted in 2020 only invokes the global emission pathways found in SR15, while leaving ambiguous whether Norway's NDC now relates primarily to the $2^{\circ} \mathrm{C}$ or the $1.5^{\circ} \mathrm{C}$ target. It does not discuss the crucial differences between the two targets, nor does it take up discussions of justice which would suggest that a rich country like Norway should go beyond the emission reductions that are required globally. The relevance of SR15 in this regard is as a device for "cooling down" the political situation of 2019, i.e., to let science talk without including more actors and issues in the process. It serves to stabilize Norway's climate policy ambitions and to justify them by reference to the monolithic authority of an IPCC report as an acceptable contribution to the goals of the Paris Agreement.

\section{Conclusions: policy relevance post-Paris}

The three examples demonstrate that policy relevance is not achieved in a linear way. Instead, policy relevance needs to be understood as a contextual matter, shaped by past events, and shaping future events - which we refer to as political situations. The invitation to the IPCC to produce SR15 was itself part of a political situation shaped by long-lasting conflicts within the UNFCCC, and likewise was the reception in Katowice, which again will shape future political situations.

Moreover, the examples have showed that policy relevance is constructed by a multitude of actors, applying different strategies: cooling down, such as the production of the vast array of policy documents underpinning the EU net-zero 2050 target; and heating up, such as multiple rounds of public hearings for re-shaping and creating legitimacy of the policy documents. In the Norwegian example, school strikers and political parties with high climate ambitions using SR15 to heat up the political situation, and the government attempting to cool it down by invoking SR15 to justify their level of ambition in a new NDC.

All examples demonstrate that policy relevance is a relational issue. The policy relevance of SR15 has not been direct, instrumental, and linear, but rather indirect, contingent and shaped by past events in feedback loops between scientific reports and political events, shaped by actors both in and beyond the IPCC, i.e., co-production. Relevance has been made through setting the societal agenda, by repackaging certain elements of SR15 and introducing these in new contexts, and legitimizing policy targets. In this way, SR15 has been made relevant at all three levels. Globally, it has strengthened the standing of the $1.5^{\circ} \mathrm{C}$ target relative to $2^{\circ} \mathrm{C}$ as the central goal of the Paris Agreement. In the EU, it has been a factor both in raising new demands for stronger climate policy and in legitimizing the EU Green Deal. At the national level, it has been used to raise Norwegian climate mitigation ambitions and further fuelling the discussion about how to manage Norwegian petroleum resources from a climate perspective. The fact that the circumstances shaping this particular outcome are specific to the national political situation, and therefore cannot be readily transferred to other countries, strengthens 
our argument that relevance must be understood contextually and relationally and by focusing on what actors do.

The notion of political situations captures these contextual dynamics, dynamics which are shaped by a multitude of actors engaging in processes of heating up and cooling down. Some actors want to "heat up", using IPCC knowledge as firewood, and other actors want to "cool down", by using IPCC knowledge as a device to stabilize political situations. In both strategies, IPCC knowledge is made relevant to support specific political purposes. The crucial difference is in how this happens: Using SR15 for the purpose of "heating up", as seen with Fridays for Future or green political parties in Norway, rests on a close interaction between science and political processes that aims to bring more actors or perspectives into policymaking. In contrast, the strategy of "cooling down" implies to keep the knowledge base stable and at and arm-length's distance from politics, using this supposed distance to stabilize and legitimize a specific political position and thus close off controversy. An example is how the EC claims to have taken SR15 "duly into account" when producing the EU Green Deal, thereby mobilizing the authority of the IPCC to fend off claims that its targets should be more or less ambitious.

Crucially, the finding that SR15 has been "made relevant" does not amount to a claim that SR15 was necessarily decisive in shaping the end-result of policymaking. By showing how actors employ different strategies, we point to the fact that policy relevance cannot be understood as a uniform phenomenon - for example, as shaping policy in a distinct way. It can also take the form of challenging policy to open up a space for contestation, or to anchor and justify existing practices. In such instances, invoking the IPCC in a policy context may have symbolic significance that goes beyond the actual content of IPCC knowledge. We argue that this, too, must be understood as part of the IPCC's relevance - particularly in the current post-Paris landscape.

As several commentators have pointed out, the Paris Agreement may mean that the IPCC will be increasingly expected to contribute directly to assessing and evaluating policy implementation and progress (Beck and Mahony 2017, 2018; Livingston and Rummukainen 2020). This can happen through the Paris Agreement's built-in mechanisms for assessing progress, such as the Global Stocktake. It can also happen at a more symbolic or discursive level, as pointed out by Aykut et al. (2020): An important aspect of the Paris Agreement is the way in which it aligns actors' expectations and enacts a certain view of "responsible conduct" (cf. Death 2011) by shaping ideas about how climate goals should be achieved. The IPCC is integral to how both these aspects of the Paris Agreement can be expected to play out - both by delivering knowledge for assessing progress under the Global Stocktake and by providing authoritative pathways that shape expectations about responsible climate action.

On this basis, we expect that the IPCC may increasingly come to be made relevant through "heating up" strategies in which IPCC knowledge is used to challenge policy at various levels. Consequently, IPCC outputs will more often be used in ways that run contrary to the IPCC's self-understanding of a clear separation between science and policy. The core objective of the IPCC, to produce consensus-based assessments reports for the governments represented in the UNFCCC, implies a mode of work that is primarily adapted to a cooling-down strategy. The more the IPCC becomes an integral part of situations of "heat", the more difficulties the organization may have keeping political processes at arm's length distance. This clearly raises new challenges for the IPCC's quest for policy relevance. Our approach to understanding policy relevance does not provide a 
universal solution to these challenges, but it does provide some lessons that may be relevant for charting the direction ahead.

From a perspective that sees policy relevance as always relational and co-created in specific political situations, the IPCC should acknowledge that the relevance of its reports is not simply a matter of how the reports themselves are developed, framed, and communicated (relevance as process), but also depends on how reports are used by different actors in political situations that stretch well beyond the IPCC's reach (relevance as outcome). Seeing relevance as something that is created in these situations does not mean that it is fully outside the IPCC's own control or that its efforts to produce or maintain relevance are useless. What it does mean, in our view, is that the IPCC should be open to more than its current dominant image of envisaging policy relevance and science-policy interactions. When COP 24 was unable to reach agreement on whether to "welcome" SR15, several IPCC contributors expressed dismay that their work was disregarded or devalued by the UNFCCC. As we have argued, however, it is misleading to see the conflict about how to receive the report as a failure to produce relevance. Rather, it was precisely because the report was made relevant in the on-going struggle over the status of the $1.5^{\circ} \mathrm{C}$ target that it became controversial at the UNFCCC level. While the IPCC and its contributors may still prefer the linear mode in which the science is clearly delineated from the translations and appropriations it undergoes in the heat of political controversies, such situations of "heating up" may in many cases be an integral part of making the IPCC's reports relevant.

Against this backdrop, we have some recommendations for the IPCC. First, the IPCC should acknowledge that policy relevance is a relational and contextual issue in which diverse actors - far beyond policy makers - contribute to produce relevance through different strategies. The IPCC is co-creating these political situations, and this is in itself part of its "policy relevance". Neither cooling down nor heating up is inherently good or bad; rather, both strategies are inevitable parts of situations of relevance-making. Therefore, the IPCC should not regret or shy away from heated processes, as relevance is produced also in political situations; heat may in fact be a sign of relevance.

Second, the IPCC can anticipate and work constructively with heated political situations by working less closed-off from key actors such as civil society and the private sector. This could for example take the form of co-producing derivative products (such as targeted materials and events) with key actors, including with national IPCC focal points. There is scope for such activities in IPCC strategy documents, but these options may be explored and employed more frequently and systematically.

Third, although the IPCC is a small organization, it coordinates an enormous network of scientists. The IPCC can to a larger extent train and encourage the scientists in its network to anticipate and stand in the heat in political situations, and not least to engage with other actors in such situations - as both scientists and citizens. In the Fridays for Future demonstrations, several climate scientists joined, giving legitimacy to the initiative, thus helping create policy relevance of the IPCC.

Finally, systematic and reflexive organizational learning may help anticipate and prepare for political situations. A good start, which is also a recommendation for future research, is to encourage and embrace systematic study of how IPCC reports are made relevant—beginning with AR6 in order to feed further lessons into the next assessment process. In this way, learning loops for policy relevance and a more reflexive engagement with the political processes both within and beyond the UNFCCC can be developed. 
Code availability Not applicable

Author contribution EATH led the study and worked on conceptualization, data collection (the UNFCCC and the EU), analysis and conclusions. BL worked on conceptualization, data collection (Norway), analysis, and conclusions. GS worked on conceptualization, analysis, and conclusions. EØ worked on data collection (the EU), analysis, and conceptualization.

Funding The Research Council of Norway, grant no. 268056.

Data availability All data is publicly available; see references.

\section{Declarations}

Conflict of interest The authors declare no competing interests.

Open Access This article is licensed under a Creative Commons Attribution 4.0 International License, which permits use, sharing, adaptation, distribution and reproduction in any medium or format, as long as you give appropriate credit to the original author(s) and the source, provide a link to the Creative Commons licence, and indicate if changes were made. The images or other third party material in this article are included in the article's Creative Commons licence, unless indicated otherwise in a credit line to the material. If material is not included in the article's Creative Commons licence and your intended use is not permitted by statutory regulation or exceeds the permitted use, you will need to obtain permission directly from the copyright holder. To view a copy of this licence, visit http://creativecommons.org/licenses/by/4.0/.

\section{References}

Agrawala S (1998a) Context and early origins of the intergovernmental panel on climate change. Clim Chang 39(4):605-620

Agrawala S (1998b) Structural and process history of the intergovernmental panel on climate change. Clim Chang 39(4):621-642

Aykut SC, Morena E, Foyer J (2020) 'Incantatory' governance: global climate politics' performative turn and its wider significance for global politics. International politics 1-22

Boasson EL, Lahn B (2017) Norway: A Dissonant Cognitive Leader? In: Wurzel RKW, Connelly J, Liefferink D (eds) The European Union in International Climate Change Politics: Still Taking a Lead? Routledge, London, pp 213-228

Barry A (2012) Political situations: knowledge controversies in transnational governance. Critic Policy Stud 6(3):324-336

Beck S (2011) Moving beyond the linear model of expertise? IPCC and the test of adaptation. Reg Environ Chang 11(2):297-306

Beck S, Mahony M (2017) The IPCC and the politics of anticipation. Nat Clim Chang 7:311-313

Beck S, Mahony M (2018) The politics of anticipation: the IPCC and the negative emissions technologies experience. Global Sustain 1:1-8

Bøyum VH, Svanes CBG, Lægreud AG, et al. (2019) I dag streiker vi for klimaet igjen. [Today we go on strike for the climate again] Aftenposten https://www.aftenposten.no/meninger/sid/i/GGOLpl/seks-klimaaktivister24-mai-streiker-vi-for-klimaet-igjen. Accessed 4 January 2021

Death C (2011) Summit theatre: exemplary governmentality and environmental diplomacy in Johannesburg and Copenhagen. Environ Politics 20(1):1-19

Edwards PN (2010) A vast machine: computer models, climate data, and the politics of global warming. MIT Press, Cambridge

Ekblom J, Baczynska G (2019) EU trumpets green Deal as its 'man on the moon moment'. Reuters https://www. reuters.com/article/us-climate-change-eu-idUSKBN1YF1NA. Accessed 10 January 2021

ENB (2016) Summary of the 44th Session of the Intergovernmental Panel on Climate Change: 17-21 October 2016. Earth negotiations bulletin (ENB), International Institute for Sustainable Development (IISD). Winnipeg, Canada 
ENB (2018) Summary of the 48th Session of the Intergovernmental Panel on Climate Change: 1-6 October 2018. Earth negotiations bulletin (ENB), International Institute for Sustainable Development (IISD). Winnipeg, Canada

EC (2018a) Communication from the Commission to the European Parliament, the European Council, the Council, the European Economic and Social Committee, the Committee of the Regions and the European Investment Bank. A Clean Planet for all: A European strategic long-term vision for a prosperous, modern, competitive and climate neutral economy. COM/(2018)/773 final

EC (2018b) In-depth analysis in support of the Commission Communication COM(2018) 773: A clean planet for All A European long-term strategic vision for a prosperous, modern, competitive and climate neutral economy

EC (2019) Communication from the Commission to the European Parliament, the European Council, The European Economic and Social Committee and the Committee of the Regions. The European Green Deal COM $/ 2019 / 640$ final

EC (2020) Regulation (EU) 2021/1119 of the European Parliament and of the Council of 30 June 2021 establishing the framework for achieving climate neutrality and amending Regulations (EC) No 401/2009 and (EU) 2018/1999 ('European Climate Law')

Eckersley R (2016) National identities, international roles, and the legitimation of climate leadership: Germany and Norway compared. Environ Politics 25(1):180-201

Edenhofer O, Minx J (2014) Mapmakers and navigators, facts and values. Science 345(6192):37-38

EU (2015) Submission by Latvia and the European Commission on behalf of the European Union and its Member States

EU (2020) Update of the NDC of the European Union and its Member States

Farand C (2019) UN report on 1.5C blocked from climate talks after Saudi Arabia disputes science. Climate Home News. https://www.climatechangenews.com/2019/06/27/un-report-1-5c-blocked-climate-talks-saudiarabia-disputes-science/. Accessed 12 November 2020

George AL, Bennett A (2005) Case studies and theory development in the social sciences. MIT Press, Cambridge Government of Norway (2015) Norway's Intended Nationally Determined Contribution. Submission by Norway to the ADP. https://www4.unfccc.int/sites/ndestaging/PublishedDocuments/Norway\%20First/ NorwayINDC\%20(Archived).pdf. Accessed 4 January 2021

Government of Norway (2019) Granavolden-plattformen. [The Granavolden platform] Political platform for the Norwegian Government. https://www.regjeringen.no/no/dokumentarkiv/regjeringen-solberg/andredokumenter/smk/2019/politisk-plattform/id2626036/. Accessed 18 October 2021

Government of Norway (2020) Update of Norway's nationally determined contribution. https://www4.unfecc. int/sites/ndcstaging/PublishedDocuments/Norway\%20First/Norway_updatedNDC_2020\%20(Updated\% 20submission).pdf. Accessed 4 January 2021

Guillemot $\mathrm{H}$ (2017) The necessary and inaccessible $1.5^{\circ} \mathrm{C}$ objective: a turning point in the relations between climate science and politics? In: Aykut SC, Foyer J, Morena E (eds) Globalising the climate: COP21 and the climatisation of global debates. Routledge, London, pp 39-56

Hermansen EAT, Sundqvist G, Yearley S, St. Clair AL, Fløttum K, Gasper D, Painter J (2018) Fra symfoni til kakofoni: Rapportene fra FNs klimapanel og reisen mot relevans. In: Bjørkdahl K (ed) Rapporten: Sjanger og styringsverktøy. Pax Forlag, Oslo, pp 127-155

Hickman L (2018) The carbon brief interview: Saudi Arabia's Ayman Shasly. Carbon Brief https://www. carbonbrief.org/the-carbon-brief-interview-saudi-arabias-ayman-shasly. Accessed 12 November 2020

Holmes MCS (2019) Tar de klimastreikendes krav til Stortinget. [Climate strikers' demands taken to Parliament] Verdens Gang https://www.vg.no/i/K38W4X. Accessed 4 January 2021

Hulme M (2016) $1.5^{\circ} \mathrm{C}$ and climate research after the Paris agreement. Nat Clim Chang 6:222-224

IPCC (2018) Global Warming of $1.5^{\circ} \mathrm{C}$. An IPCC Special Report on the impacts of global warming of $1.5^{\circ} \mathrm{C}$ above pre-industrial levels and related global greenhouse gas emission pathways, in the context of strengthening the global response to the threat of climate change, sustainable development, and efforts to eradicate poverty. [Masson-Delmotte, V., P. Zhai, H.-O. Pörtner, D. Roberts, J. Skea, P.R. Shukla, A. Pirani, W. Moufouma-Okia, C. Péan, R. Pidcock, S. Connors, J.B.R. Matthews, Y. Chen, X. Zhou, M.I. Gomis, E. Lonnoy, T. Maycock, M. Tignor, and T. Waterfield (eds.)]

IPCC (2021a) About the IPCC. IPCC website https://www.ipcc.ch/about/. Accessed 10 January 2021

IPCC (2021b) Organization. IPCC website archive https://archive.ipcc.ch/organization/organization.shtml. Accessed 10 January 2021

Jabbour J, Flachsland C (2017) 40 years of global environmental assessments: a retrospective analysis. Environ Sci Pol 77:193-203

Jasanoff S (2004) Ordering knowledge, ordering society. In: Jasanoff S (ed) States of knowledge. The coproduction of science and social order. Routledge, London, pp 13-45 
Jordan A, Huitema D, Van Asselt H, Forster J (eds) (2018) Governing climate change: polycentricity in action? Cambridge University Press, Cambridge

Lahn B (2018) In the light of equity and science: scientific expertise and climate justice after Paris. International Environmental Agreements: Politics, Law and Economics 18(1):29-43

Lahn B (2020) Changing climate change: The carbon budget and the modifying-work of the IPCC. Social Studies of Science. https://doi.org/10.1177/0306312720941933

Lee H (2015) Turning the focus to solutions. Science 350:1007

Livingston JE, Lövbrand E, Olsson JA (2018) From climates multiple to climate singular: maintaining policyrelevance in the IPCC synthesis report. Environ Sci Pol 90:83-90

Livingston JE, Rummukainen M (2020) Taking science by surprise: the knowledge politics of the IPCC special report on 1.5 degrees. Environ Sci Pol 112:10-16

Lövbrand E (2011) Co-producing European climate science and policy: a cautionary note on the making of useful knowledge. Sci Public Policy 38(3):225-236

Mahony M (2015) Climate change and the geographies of objectivity: the case of the IPCC's burning embers diagram. Trans Inst Br Geogr 40(2):153-167

Mahony M, Hulme M (2018) Epistemic geographies of climate change: Science, space and politics. Prog Hum Geogr 42(3):395-424. https://doi.org/10.1177/0309132516681485

Marres N (2007) The issues deserve more credit: pragmatist contributions to the study of public involvement in controversy. Soc Stud Sci 37(5):759-778

Mathiesen K, Sauer N (2018) EU: breaching 1.5C would trigger cascade of negative effects. Climate Home News. https:/www.climatechangenews.com/2018/10/05/eu-breaching-1-5c-trigger-cascade-negativeeffects/. Accessed 10 January 2021

Miller CA (2004) Climate science and the making of a global political order. In: Jasanoff S (ed) States of knowledge. The co-production of science and social Order. Routledge, London, pp 46-66

Niranjan A (2019) Global climate strike protest in Berlin bridges generations as adults join in. Deutsche Welle https://www.dw.com/en/global-climate-strike-protest-in-berlin-bridges-generations-as-adults-join-in/a50516302. Accessed 10 January 2021

O’Neill S, Williams HT, Kurz T, Wiersma B, Boykoff M (2015) Dominant frames in legacy and social media coverage of the IPCC fifth assessment report. Nat Clim Chang 5(4):380-385

Oppenheimer M, Petsonk A (2005) Article 2 of the UNFCCC: historical origins, recent interpretations. Clim Chang 73(3):195-226

Rajamani L (2016) Ambition and differentiation in the 2015 Paris agreement: interpretive possibilities and underlying politics. Intl Comparative Law Quart 65(2):493-514

Randalls S (2010) History of the $2^{\circ} \mathrm{C}$ climate target. Wiley Interdiscip Rev Clim Chang 1(4):598-605

Rankin J (2019) European green deal to press ahead despite polish targets opt-out. The Guardian https://www. theguardian.com/environment/2019/dec/13/european-green-deal-to-press-ahead-despite-polish-targets-optout. Accessed 10 January 2021

Riousset P, Flachsland C, Kowarsch M (2017) Global environmental assessments: impact mechanisms. Environ Sci Pol 77:260-267

Tschakert $\mathrm{P}(2015) 1.5^{\circ} \mathrm{C}$ or $2^{\circ} \mathrm{C}$ : a conduit's view from the science-policy interface at COP20 in Lima, Peru. Climate change responses 2(1):3

Sundqvist G (2014) 'Heating up'or 'cooling down'? Analysing and performing broadened participation in technoscientific conflicts. Environment and Planning A, 46(9), 2065-2079

Sundqvist G, Bohlin I, Hermansen EAT, Yearley S (2015) Formalization and separation: A systematic basis for interpreting approaches to summarizing science for climate policy. Social Studies of Science, 45(3):416-440

Sundqvist G, Gasper D, St. Clair AL, Hermansen EAT, Yearley S, Øvstebø Tvedten I, Wynne B (2018). One world or two? Science-policy interactions in the climate field. Critical Policy Studies, 12(4):448-468

UNFCCC (2009) The Copenhagen Accord. United Nations framework convention on climate change. Conference of the parties (COP) fifteenth session. 2/CP.15

UNFCCC (2015) Adoption of the Paris agreement. United Nations framework convention on climate change. Conference of the parties (COP) twenty-first session. FCCC/CP/2015/L.9/rev.1

van der Sluijs J, van Eijndhoven J, Shackley S, Wynne B (1998) Anchoring devices in science for policy: the case of consensus around climate sensitivity. Soc Stud Sci 28(2):291-323

Watson RT (2005) Turning science into policy: challenges and experiences from the science-policy interface. Philos Trans R Soc B 360(1454):471-477

Publisher's note Springer Nature remains neutral with regard to jurisdictional claims in published maps and institutional affiliations. 